\title{
Distribution of Kainate Receptor Subunits at Hippocampal Mossy Fiber Synapses
}

\author{
Melanie Darstein, ${ }^{1}$ Ronald S. Petralia, ${ }^{2}$ Geoffrey T. Swanson, ${ }^{3}$ Robert J. Wenthold, ${ }^{2}$ and Stephen F. Heinemann ${ }^{1}$ \\ ${ }^{1}$ Molecular Neurobiology, The Salk Institute for Biological Studies, La Jolla, California 92037, ${ }^{2}$ Laboratory of Neurochemistry, National Institute on \\ Deafness and Other Communication Disorders-National Institutes of Health, Bethesda, Maryland 20892-8027, and ${ }^{3}$ Department of Pharmacology and \\ Toxicology, University of Texas Medical Branch, Galveston, Texas 77555
}

\begin{abstract}
Kainate receptors function as mediators of postsynaptic currents and as presynaptic modulators of synaptic transmission at mossy fiber synapses. Despite intense research into the physiological properties of mossy fiber kainate receptors, their subunit composition in the presynaptic and postsynaptic compartments is unclear. Here we describe the distribution of kainate receptor subunits in mossy fiber synapses using subunit-selective antibodies and knock-out mice. We provide morphological evidence for the presynaptic localization of KA1 and KA2 receptor subunits at mossy fiber synapses. Immunogold staining for KA1 and KA2 was commonly seen at synaptic contacts and in vesicular structures. Postsynaptic labeling in dendritic spines was also observed. Although KA1 predominantly showed presynaptic localization, KA2 was concentrated to a greater degree on postsynaptic membranes. Both subunits coimmunoprecipitated from hippocampal membrane extracts with GluR6 but not GluR7 subunits. These results demonstrate that KA1 and KA2 subunits are localized presynaptically and postsynaptically at mossy fiber synapses where they most likely coassemble with GluR6 subunits to form functional heteromeric kainate receptor complexes.
\end{abstract}

Key words: KA1 kainate receptor subunit; KA2 kainate receptor subunit; presynaptic kainate receptors; coassembly; knock-out mice; hippocampus; mossy fiber

\section{Introduction}

Most of the excitatory synaptic transmission in the brain occurs at glutamatergic synapses and is mediated by the NMDA-, AMPA-, and kainate-type of ionotropic glutamate receptors (Hollmann and Heinemann, 1994; Dingledine et al., 1999). Kainate receptor complexes are composed of five different protein subunits: GluR5, GluR6, GluR7, KA1, and KA2 (Hollmann and Heinemann, 1994). GluR5-7 subunits form functional homomeric channels (Sommer et al., 1992; Egebjerg and Heinemann, 1993; Schiffer et al., 1997). Although KA1 and KA2 subunits are not able to form functional homomers, they can coassemble with GluR5, GluR6, or GluR7 to form heteromeric receptors with distinct physiological properties (Werner et al., 1991; Herb et al., 1992; Schiffer et al., 1997). The precise subunit composition of native kainate receptors is not known with certainty, and overlapping expression patterns of subunit mRNAs in the brain (Wisden and Seeburg, 1993; Bahn et al., 1994) make it likely that kainate receptors exist in diverse subsets of heteromeric assemblies. To understand the physiological properties of neuronal kai-

\footnotetext{
Received Oct. 15, 2003; revised July 3, 2003; accepted July 9, 2003.

This work was supported by grants from the Deutsche Forschungsgemeinschaft (M.D.), National Alliance for Research on Schizophrenia and Depression (M.D.), and National Institutes of Health (G.T.S., S.F.H.). We thank Conny Maron for technical help, Dr. Y.-X. Wang for help in the immunogold labeling study, and Dr. A. Contractor for critically reading this manuscript.

Correspondence should be addressed to M. Darstein, Institute of Anatomy and Cell Biology I, University of Freiburg, Albertstrasse 17, D-79104 Freiburg, Germany. E-mail: melanie.darstein@anat.uni-freiburg.de.

Copyright $\odot 2003$ Society for Neuroscience $\quad 0270-6474 / 03 / 238013-07 \$ 15.00 / 0$
}

nate receptors, it is essential to identify the molecular composition of individual kainate receptor populations.

Kainate receptors play an important role in excitatory transmission at hippocampal mossy fiber-CA3 pyramidal cell synapses. Postsynaptic receptors contribute to excitatory currents (Castillo et al., 1997; Vignes and Collingridge, 1997) and presynaptic kainate receptors modulate the strength of synaptic transmission (Kamiya and Ozawa, 2000; Contractor et al., 2001; Lauri et al., 2001; Schmitz et al., 2001a). The subunit composition of mossy fiber kainate receptors has been the subject of some debate as a result of contrasting findings in pharmacological and genetic studies (Vignes and Collingridge, 1997; Bortolotto et al., 1999; Contractor et al., 2000, 2001; Lauri et al., 2001). Electron microscopic studies found KA2 and GluR6/7 subunit immunoreactivity in postsynaptic sites of mossy fiber synapses but not at presynaptic mossy fiber terminals (Petralia et al., 1994). Radioligand binding studies, on the other hand, have reported a high labeling density of $\left[{ }^{3} \mathrm{H}\right]$ kainate in the stratum lucidum (Monaghan and Cotman, 1982), which was significantly reduced after destruction of granule cell bodies (Represa et al., 1987), suggesting that the high-affinity kainate receptor subunits KA1 and KA2 are localized on mossy fiber presynaptic terminals. Because of the limited tools previously available to study kainate receptors, the description of the anatomical localization of individual subunit proteins to different brain compartments is incomplete, and uncertainty remains regarding the subunits forming mossy fiber kainate receptors.

We have generated and used subunit-specific antibodies to 
describe the subcellular localization of different kainate receptor subunits in hippocampal mossy fibers. Our primary objectives were twofold: first, to describe the distribution of KA1 and KA2 subunits using specific anti-subunit antibodies; and second, to clarify the localization of the GluR6 and GluR7 subunits, which are expressed in overlapping populations of neurons in the dentate gyrus and CA3 regions. Our results support both presynaptic and postsynaptic localization of mossy fiber kainate receptors and suggest that these receptors are heteromeric complexes composed of KA1 and KA2 subunits coassembled with GluR6 subunits.

\section{Materials and Methods}

Generation of antibodies. Rabbit polyclonal antibodies were raised against purified synthetic peptides corresponding to the C terminus of KA1 (SPARSEESLEWDKTTNSSEPE) and KA2 (SPPRPRPGPTGPRELTEHE). A cysteine residue was added at the $\mathrm{N}$ terminus to facilitate conjugation to the carrier protein keyhole limpet hemocyanin. Peptide synthesis, rabbit immunization, sera collection from rabbits, and subsequent affinity purification of the crude serum against the immobilized immunizing peptide were performed by Bethyl Laboratories (Montgomery, TX).

Cell culture and transfections. Human embryonic kidney 293T (HEK293T) cells were maintained in DMEM supplemented with 100 $\mu \mathrm{g} / \mathrm{ml}$ penicillin, $100 \mu \mathrm{g} / \mathrm{ml}$ streptomycin, and $10 \%$ fetal calf serum at $37^{\circ} \mathrm{C}$ in $5 \% \mathrm{CO}_{2}$. Cells were plated in six-well multiwell plates and transiently transfected with receptor cDNAs the next day by standard calcium-phosphate precipitation. Two days after transfection, cells were washed and subsequently lysed by adding lysis buffer $(50 \mathrm{~mm}$ Tris, $\mathrm{pH}$ 7.4, and $1 \%$ Triton X-100) containing a mixture of protease inhibitors. HEK293T cell lysates were solubilized for $45 \mathrm{~min}$ at $4^{\circ} \mathrm{C}$, and insoluble material was removed by centrifugation. The samples were heated in Laemmli SDS sample buffer at $70^{\circ} \mathrm{C}$ for subsequent electrophoresis and immunoblotting.

Membrane preparations from mouse brain. Membranes were prepared from brain tissue of mice with the following genotypes: wild type, GluR6 $^{-1-}$, GluR7 ${ }^{-1-}$, and KA2 ${ }^{-1-}$. Wild-type, GluR6 ${ }^{-1-}$, and KA2 ${ }^{-1-}$ mice had a hybrid $129 \mathrm{SvEv} / \mathrm{C} 57 \mathrm{~b} / 6$ background, whereas the genetic background of the GluR7 ${ }^{-/-}$mice was isogenic $129 \mathrm{SvEv}$. To prepare membranes, either whole brains or dissected hippocampi were homogenized in $10 \mathrm{vol}$ of ice-cold buffer containing $10 \mathrm{~mm}$ Tris, $\mathrm{pH}$ 7.4, $320 \mathrm{~mm}$ sucrose, $1 \mu \mathrm{g} / \mathrm{ml}$ leupeptin, $1 \mu \mathrm{g} / \mathrm{ml}$ pepstatin, $2.5 \mu \mathrm{g} / \mathrm{ml}$ aprotinin. After centrifugation at $3000 \times g$ for $5 \mathrm{~min}$ at $4^{\circ} \mathrm{C}$, the supernatant was recovered and further centrifuged at $30,000 \times g$ for $30 \mathrm{~min}$ at $4^{\circ} \mathrm{C}$. The pellet was resuspended in $50 \mathrm{~mm}$ Tris buffer, $\mathrm{pH}$ 7.4, containing $1 \%$ Triton X-100 and protease inhibitors.

Immunoprecipitations. For immunoprecipitation, HEK293T cell lysates or mouse plasma membranes were incubated with $2 \mu \mathrm{g}$ of the anti-KA1 antibody, the anti-KA2 antibody, or a rabbit anti-GluR6/7 antibody (Upstate Biotechnology, Lake Placid, NY) for $2 \mathrm{hr}$, followed by incubation with protein A Sepharose for $45 \mathrm{~min}$ at $4^{\circ} \mathrm{C}$. The beads were then washed three times with $50 \mathrm{~mm}$ Tris, $\mathrm{pH} 7.4$, containing $0.1 \%$ Triton $\mathrm{X}-100$. Samples were either further processed for deglycosylation or analyzed by electrophoresis and immunoblotting after heating at $70^{\circ} \mathrm{C}$ in SDS sample buffer.

Deglycosylations. Immunoprecipitated samples were resuspended in reaction buffer (20 mM sodium phosphate, $\mathrm{pH} 6,0.4 \%$ SDS, $1 \%$ 2-mercaptoethanol), denatured for $4 \mathrm{~min}$ at $100^{\circ} \mathrm{C}$, incubated for $1-2 \mathrm{hr}$ at $37^{\circ} \mathrm{C}$ containing either no glycosidase or $0.1 \mathrm{U} \mathrm{N}$-glycosidase F (Glyko, Novato, CA), and heated in SDS sample buffer for subsequent immunoblot analysis.

Immunolabeling and imaging analysis. Adult mice were transcardially perfused with $4 \%$ paraformaldehyde. Brains were removed, cryoprotected in $20 \%$ sucrose in PBS, frozen, and cut into $30-\mu \mathrm{m}$-thick sagittal sections on a sliding microtome. Sections were washed in PBS, incubated for $1 \mathrm{hr}$ in PBS solution of 5\% goat serum and 0.1\% Triton X-100, and incubated with either the anti-KA1 or anti-KA2 antibodies that we have generated or with polyclonal anti-R6/7 antibody (Upstate Biotechnology) in PBS containing goat serum and $0.1 \%$ Triton X-100 overnight at
A

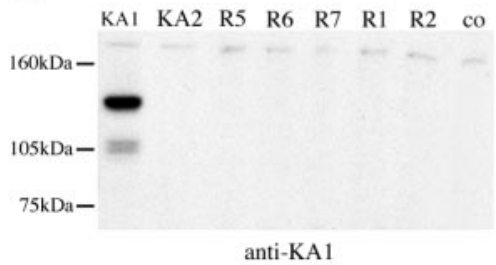

B

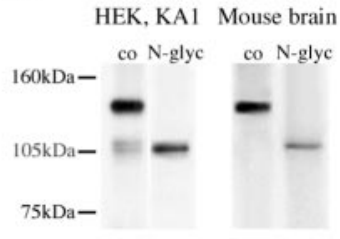

anti-KA1

Figure 1. Antibody characterization. A, Immunoblot analysis of HEK293T cells transfected with glutamate receptor CDNAs using anti-KA1 antibodies. KA1 immunoreactivity is seen in lysates of HEK293T cells transfected with KA1 CDNA but not of cells transfected with CDNA of KA2, GFP-GluR5 (R5), GluR6 (R6), GluR7 (R7), GluR1 (R1), or GluR2 (R2) or of untransfected cells (Co). B, Deglycosylation with $\mathrm{N}$-glycosidase F reduces the size of KA1-immunoreactive bands in HEK293T cell lysates and in mouse brain tissue to $105 \mathrm{kDa}$ [absence (co) and presence ( $\mathrm{N}$-glyc) of N-glycosidase F).

$4^{\circ} \mathrm{C}$. Antibodies were diluted to a final concentration of $1 \mu \mathrm{g} / \mathrm{ml}$. The tissue was washed and incubated with biotinylated goat anti-rabbit secondary antibody (Vector Laboratories), followed by incubation with $\mathrm{ABC}$ elite kit (Vector Laboratories) for $1 \mathrm{hr}$ and subsequent visualization with peroxidase-reduced diaminobenzidine (Sigma, St. Louis, MO). The sections were mounted on slides and analyzed using light microscopy.

Immunogold labeling. The postembedding method has been described in detail (Petralia and Wenthold, 1999). Animals were anesthetized and perfused with $4 \%$ paraformaldehyde plus $0.5 \%$ glutaraldehyde in $0.1 \mathrm{M}$ phosphate buffer. Parasagittal sections of the hippocampus were cryoprotected in $30 \%$ glycerol and frozen in liquid propane in a Leica electron microscopy (EM) cryopreparation chamber. Frozen sections were immersed in $1.5 \%$ uranyl acetate in methanol at $-90^{\circ} \mathrm{C}$ in a Leica automatic freeze substitution instrument, infiltrated with Lowicryl HM-20 resin at $-45^{\circ} \mathrm{C}$, and polymerized with ultraviolet light. Thin sections were incubated in $0.1 \%$ sodium borohydride plus $50 \mathrm{~mm}$ glycine in Tris-buffered saline plus $0.1 \%$ Triton X-100 (TBST), followed by $10 \%$ normal goat serum in TBST, primary antibody in $1 \%$ normal goat serum in TBST (overnight at room temperature or $4^{\circ} \mathrm{C}$; all other steps were performed at room temperature), and immunogold (10 nm; Amersham) in 1\% normal goat serum in TBST plus $0.5 \%$ polyethylene glycol (MW 20,000; $1 \mathrm{hr}$ ); the sections finally were stained in uranyl acetate and lead citrate. Two (KA2) or three (KA1) mice and one rat (KA1) were used for immunogold localization. All animal studies were done in accordance with the National Institutes of Health Guide for the Care and Use of Laboratory Animals (National Institutes of Health publication 85-23) under National Institute on Deafness and Other Communication Disorders protocols 874-98 and 991-00. Brightness and contrast of final figures were modified using Adobe Photoshop.

For measurement of the vertical distribution of gold particles, sections of hippocampus were labeled with $5 \mathrm{~nm} \mathrm{~F}\left(\mathrm{ab}^{\prime}\right) 2$ gold (Goldmark brand; Ted Pella, Redding). This gives an improved spatial resolution of $\sim 15$ $\mathrm{nm}$ in any direction (compared with $\sim 20 \mathrm{~nm}$ with $10 \mathrm{~nm} \mathrm{IgG}$ gold) (Merighi, 1992). Random areas of the CA3 stratum lucidum were selected from two animals, and gold particles within $50 \mathrm{~nm}$ of either the presynaptic or postsynaptic membrane were measured in the vicinity of active zones as well as neighboring synaptic membranes. Distances were computed from the edge of the membrane to the edge of the gold particle.

\section{Results}

\section{Characterization of subunit-specific antibodies}

To study the distribution and assembly of high-affinity kainate receptor subunits in the mouse brain, we raised polyclonal antibodies against the unique $\mathrm{C}$-terminal domains of the glutamate receptor subunits KA1 and KA2. The subunit specificity of the anti-KA1 antibody was tested in HEK293T cells transiently transfected with cDNAs coding for either KA1 or other glutamate receptor subunits. In immunoblot experiments, the anti-KA1 antibody specifically recognized KA1 but did not detect any other kainate receptor subunits (GluR5-7, KA2) or AMPA receptor subunits (GluR1, GluR2) (Fig. 1A). The expression of these sub- 


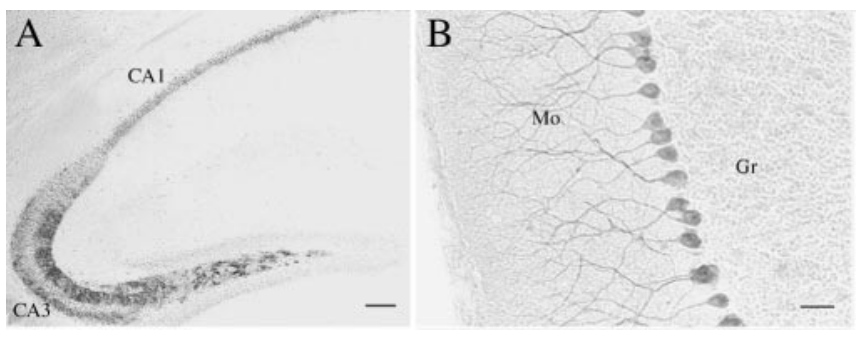

Figure 2. Distribution of KA1 protein in mouse brain. $A$, KA1 immunoperoxidase staining in the hippocampus. KA1 immunoreactivity is prominent in the polymorphic layer of the $D G$, in the stratum lucidum of $C A 3$, and in the pyramidal cell layer of $C A 1$. No staining is visible in the DG granule cell layer or the CA3 pyramidal cell layer. $B, K A 1$ immunoreactivity in the cerebellum. Staining is confined to Purkinje cells. Mo, Molecular layer; GR, granule cell layer. Scale bars: $A, 75$ $\mu \mathrm{m} ; B, 50 \mu \mathrm{m}$.

units was verified using antibodies directed against the respective subunits or, in the case of green fluorescent protein (GFP)GluR5, against GFP (data not shown). In lysates from KA1transfected HEK293T cells, anti-KA1 recognized one major protein band with an approximate molecular weight of $125 \mathrm{kDa}$ as well as two lighter bands at $\sim 107$ and $105 \mathrm{kDa}$, with the latter corresponding to the predicted molecular weight of KA1. Deglycosylation with $N$-glycosidase F reduced the $125 \mathrm{kDa}$ band to 105 $\mathrm{kDa}$ (Fig. $1 \mathrm{~B}$ ), suggesting that the $125 \mathrm{kDa}$ band represents the mature, glycosylated form of the KA1 subunit. $N$-glycosylation of ionotropic glutamate receptors has been described previously (for review, see Hollmann and Heinemann, 1994). In mouse brain extracts the antibody detected a protein of $125 \mathrm{kDa}$ molecular weight that, after incubation with $N$-glycosidase F, was reduced to the $105 \mathrm{kDa}$ protein (Fig. $1 B$ ).

As shown previously, the anti-KA2 antibody recognized an immunopositive band of $\sim 120 \mathrm{kDa}$ MW in brain extracts from wild-type mouse but did not give any signal in the $\mathrm{KA} 2^{-1-}$ mouse (Contractor et al., 2003). These experiments demonstrated that the antibodies were specific for the KA1 and KA2 subunits, respectively, and were used for subsequent localization and assembly studies.

Light microscopic distribution of KA1 protein in mouse brain Because previous studies found KA1 mRNA and protein expression confined mainly to the hippocampus and cerebellum (Werner et al., 1991; Bahn et al., 1994; Fogarty et al., 2000), we first studied the regional distribution of KAl protein in mouse brain sections. KA1 immunoreactivity was restricted predominantly to specific areas of these two brain regions, consistent with earlier reports. In the hippocampus, KA1 protein was expressed abundantly in the polymorphic layer of the dentate gyrus (DG), in the stratum lucidum, and in the area of infrapyramidal projections from the DG. Somata and dendrites of DG granule cells and of CA3 pyramidal cells were devoid of KA1 immunostaining (Fig. $2 A)$. The punctate staining pattern observed in the hilar region and CA3 area was reminiscent of terminals of the hippocampal mossy fibers, which originate from the DG granule cells. Some weak neuropilar staining was also detected in the stratum radiatum of CA3. In the CA1 region, KA1 staining was visible in the soma and proximal dendrites of the pyramidal cells. In the cerebellum, KA1 staining was observed in cerebellar Purkinje cell bodies and their dendritic arborizations but not in the granule layer or in molecular layer interneurons (Fig. 2 B). Other neurons labeled with the anti-KA1 antibody were scattered throughout layers II and V of the cerebral cortex (data not shown).
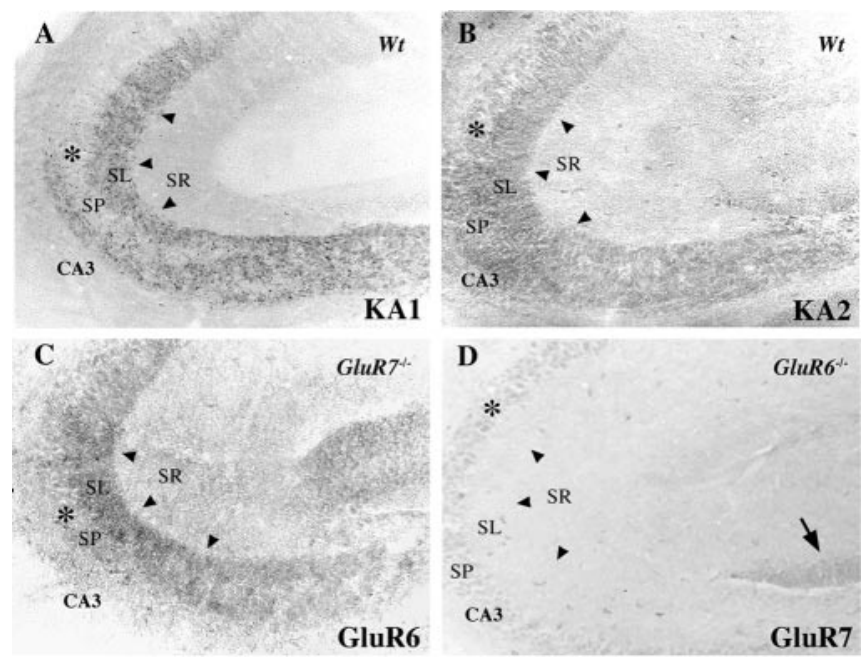

Figure 3. Distribution of kainate receptor subunits in hippocampal mossy fiber synapses. $A$, KA1 immunoperoxidase staining in the stratum lucidum (arrowheads) of the hippocampus in wild-type mice. CA3 pyramidal cells (asterisk) are devoid of staining. B, KA2-immunopositive staining in the stratum lucidum and the pyramidal cell layer of the CA3 area in wild-type mice. C, Immunostaining using GluR6/7 antibodies in GluR7 ${ }^{-1-}$ mice shows GluR6-specific labeling in the stratum lucidum and the CA3 pyramidal cell layer. D, GluR6/7 antibody does not reveal any staining in the stratum lucidum of GluR6 ${ }^{-1-}$ mice but labels the DG granule cell layer (arrow). SL, Stratum lucidum; SP, stratum pyramidale; SR, stratum radiatum.

\section{Distribution of kainate receptor subunits in mossy fiber synapses}

We compared the distribution of the kainate receptor subunit proteins KA1, KA2, GluR6, and GluR7 in the stratum lucidum and pyramidal layer of the hippocampal CA3 region on the light microscopic level in mouse brain sections. As described above, KA1 showed a punctate staining pattern in this area but did not stain the somata of CA3 pyramidal cells (Fig. 3A). KA2 immunostaining appeared in the stratum lucidum as well as in the pyramidal cell layer (Fig. 3B). This matched well with the subunit distribution observed previously using a different KA2 antibody (Petralia et al., 1994).

GluR6 and GluR7 mRNA are both expressed in dentate granule cells (Bureau et al., 1999) and therefore could contribute to formation of presynaptic kainate receptors on mossy fiber axons. To determine the distribution of GluR6 and GluR7 proteins independently, we stained hippocampal sections from knock-out mice lacking either the GluR7 (Fig. 3C) or the GluR6 subunit (Fig. 3D) with a polyclonal antibody that recognizes both GluR6 and GluR7 subunits. In the GluR7 ${ }^{-1-}$ mice, GluR6-specific immunoreactivity was strong in the stratum lucidum and the CA3 pyramidal cell layer (Fig. 3C). In contrast, the stratum lucidum did not stain in sections from the GluR6 $6^{-1-}$ mice, suggesting that the GluR7 subunit may not contribute to kainate receptors in mossy fibers. Pyramidal cell nuclei were stained only very lightly in sections from GluR6 ${ }^{-1-}$ mice (Fig. 3D).

\section{Ultrastructural localization of kainate receptor subunits in mossy fiber synapses}

To determine whether high-affinity kainate receptor subunits are located on the presynaptic and postsynaptic sides of mossy fiber synapses, we performed immunogold EM on sections of hippocampus stained for either KA1 or KA2 subunits. In the stratum lucidum, KA1 immunogold labeling was observed on presynaptic mossy fiber boutons and, to a lesser degree, in postsynaptic spines (Fig. 4A-D). Presynaptically, synaptic membranes and in- 
ternal vesicle-like structures exhibited labeling. A subset of gold particles were at or near active zones. Postsynaptic particles also were located in synaptic and internal sites (Fig. 4A-D).

KA2 immunogold labeling had a similar distribution pattern to KA1, in vesicles and synaptic sites (Fig. 4E-G). Analogous immunogold labeling with the polyclonal anti-GluR6/7 antibody was unsuccessful.

To analyze the vertical distribution of gold particles, $5 \mathrm{~nm} \mathrm{~F}\left(\mathrm{ab}^{\prime}\right) 2$ gold was used for immunolabeling of KA1 and KA2 proteins in hippocampal sections. This gives an increased spatial resolution of $\sim 15 \mathrm{~nm}$ (Merighi, 1992) to more accurately locate the particles to either the presynaptic or the postsynaptic side of the synaptic cleft. Analysis of the gold particles measured within $50 \mathrm{~nm}$ from the presynaptic and postsynaptic membrane revealed that KA1 and KA2 are concentrated within 20-30 $\mathrm{nm}$ of the synaptic membrane (Fig. 5). For KA1 subunits, the major peak of distribution was on the presynaptic membrane, and a smaller peak of distribution was near the postsynaptic membrane in both synaptic and extrasynaptic zones. Although there is a substantial concentration at synaptic sites, the relative amounts of presynaptic versus postsynaptic labeling is a little more prevalent in extrasynaptic sites. KA2 subunits were located predominantly on the postsynaptic membrane in synaptic and extrasynaptic areas (Fig. 5, graphs).

\section{Assembly of kainate receptor subunits in mouse hippocampus}

We next studied biochemical interactions between kainate receptor subunits in vivo in a series of coimmunoprecipitation experiments using hippocampal membrane preparations from wild-type mice and mice lacking the KA2, GluR6, or GluR7
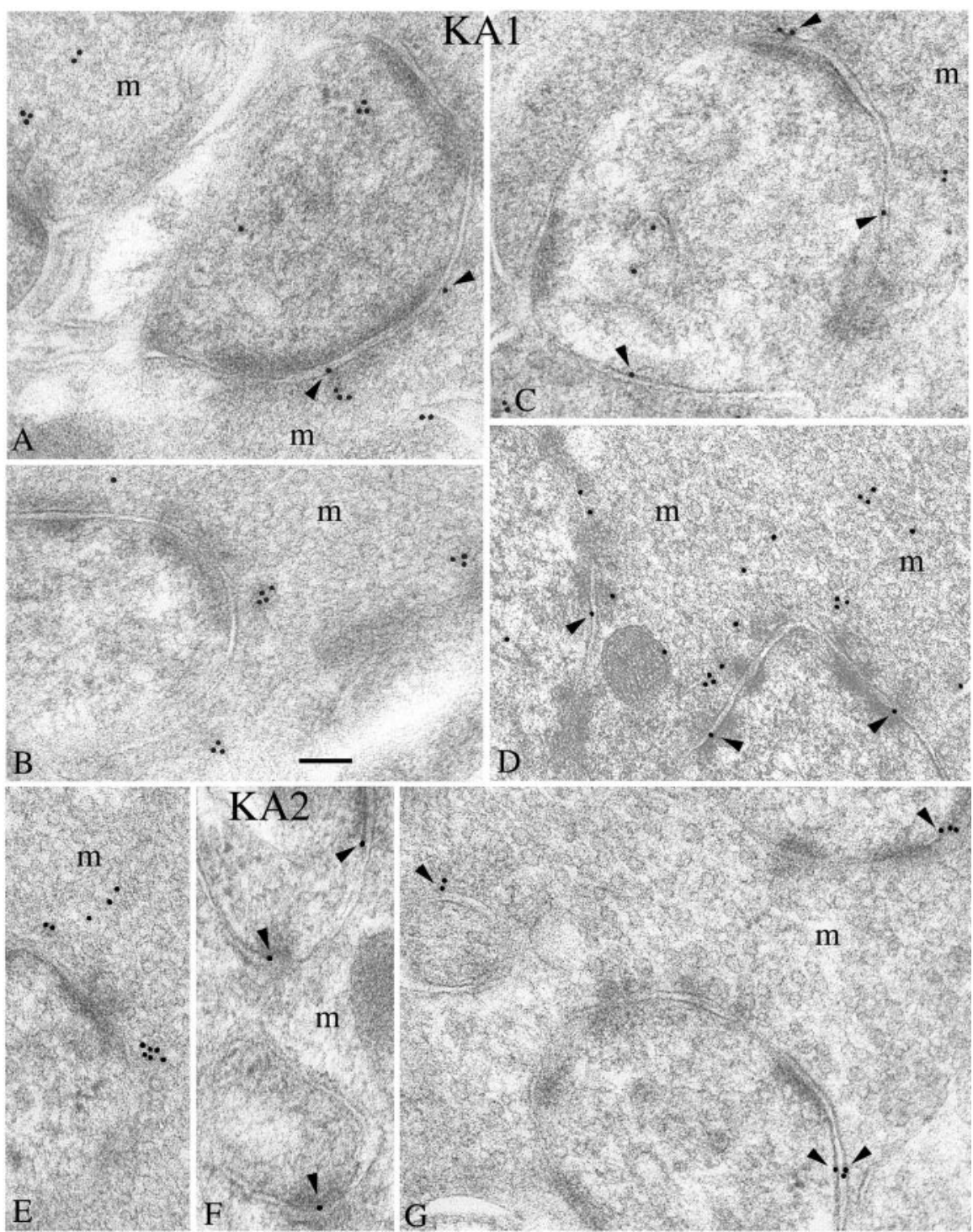

Figure 4. Ultrastructural localization of kainate receptor subunits at mossy fiber synapses. Immunogold localization of labeling for KA1 $(A-D)$ or KA2 $(E-G)$ in the CA3 stratum lucidum of the mouse hippocampus. Localization of gold labeling was common in the presynaptic mossy terminals $(m)$ as well as in postsynaptic spines. In the mossy terminals, some labeling appears to be concentrated in vesiculate structures $(A, B, D, E, G)$. Gold often is associated with the presynaptic or postsynaptic cell membranes (arrowheads). Scale bar, $100 \mathrm{~nm}$. subunits. In wild-type mouse hippocampus, anti-GluR6/7 antibody coprecipitated KA1 subunit protein; as well, anti-KA1 antibody coprecipitated GluR6/7 subunit protein (Fig. 6A), demonstrating that KA1 subunits coassemble with GluR6 or GluR7, or both. In contrast, KA1 did not coimmunoprecipitate with the AMPA receptor subunit GluR1. We performed similar immunoprecipitation experiments using hippocampi from GluR6 ${ }^{-1-}$ and GluR7 ${ }^{-1-}$ mice to analyze whether KA1 subunits interact with one or both of these subunits. Hippocampal preparations from GluR6 $^{-/-}$and GluR7 $^{-1-}$ mice had levels of KA1 subunit protein similar to hippocampus from wild-type mice, suggesting that there was not a compensatory change in expression of KAl subunit in the knock-out mice. KA1 subunits coprecipitated with GluR6/7 antibodies in the hippocampus of GluR7 ${ }^{-1-}$ mice, but not in GluR6 $^{-1-}$ mice (Fig. $6 B$ ), suggesting that KA1 predominantly coassembles with GluR6, but not GluR7, subunits in the mouse hippocampus (in agreement with our immunohistochemical localization of these subunits).

Coprecipitation of proteins with anti-KA2 antibodies yielded KA1 and GluR6/7 immunoreactivity from hippocampal membranes from wild-type mice but not $\mathrm{KA}^{-1-}$ mice (Fig. $7 A$ ), supporting other evidence that KA2 subunits coassemble with KA1 and GluR6/7 in the hippocampus. As with KA1, coprecipitations from GluR6 ${ }^{-1-}$ and GluR7 ${ }^{-1-}$ mice suggest that KA2 subunits selectively assemble with GluR6 but not GluR7 subunits in the hippocampus (Fig. 7B).

\section{Discussion}

We localized kainate receptor subunits at mossy fiber synapses using subunit-selective antibodies. Recent physiological studies have implicated kainate receptors in multiple aspects of mossy fiber function (for review, see Schmitz et al., 2001b). Our current study supports this hypothesis. On the light microscopic level, the mossy fiber pathway was immunopositive for KA1, KA2, and GluR6 subunits, with GluR7 subunits confined to the dentate gyrus. Immunogold EM studies revealed that KA1 and KA2 sub- 


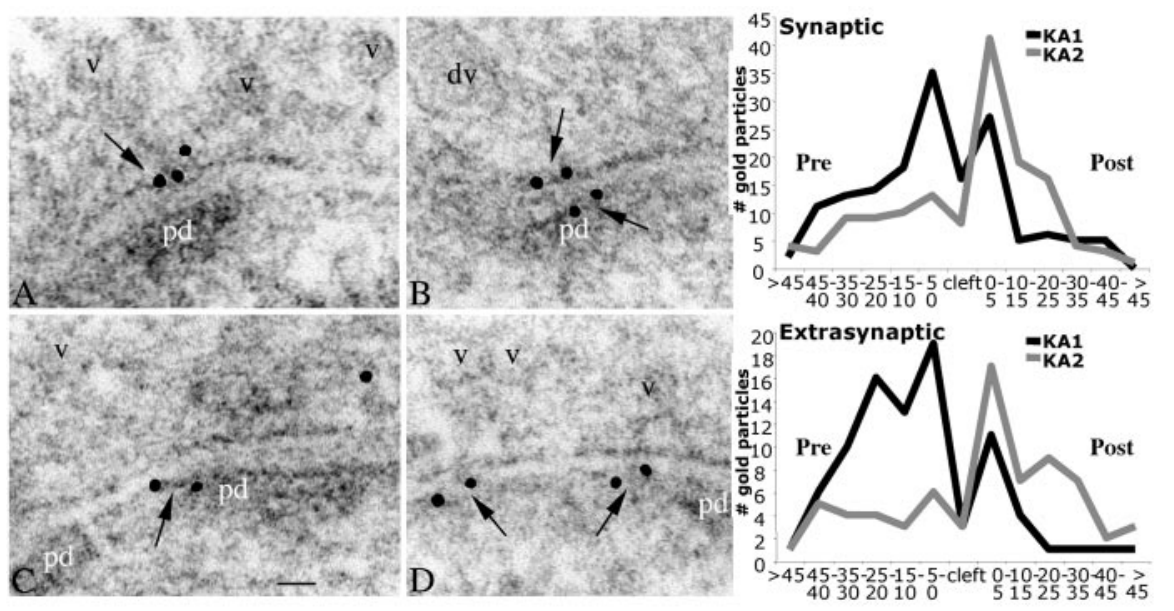

Figure 5. Distribution of immunogold particles at mossy fiber synapses. High-magnification micrographs of CA3 stratum lucidum of hippocampus labeled with $\operatorname{KA1}(A, B)$ and $\operatorname{KA2}(C, D)$, using $5 \mathrm{~nm} \mathrm{~F}\left(\mathrm{ab}^{\prime}\right) 2$ gold. Note labeling (arrows) along the presynaptic or postsynaptic membranes $(A-C)$ and on the postsynaptic side of extrasynaptic membranes $(D)$. For orientation, presynaptic vesicles (v), a presynaptic dense-cored vesicle (dv), and the postsynaptic density (pd) are labeled. Scale bar, $20 \mathrm{~nm}$. Graphs compare the vertical distribution of KA1 (244 gold particles) and KA2 (211 gold particles) in the active and extrasynaptic zones, from $50 \mathrm{~nm}$ presynaptic (Pre; left) to $50 \mathrm{~nm}$ postsynaptic (Post; right). KA1 shows a major peak on the presynaptic membrane $(5-0 \mathrm{~nm})$ and a slightly smaller one on the postsynaptic membrane $(0-5 \mathrm{~nm})$, whereas KA2 shows a major peak only on the postsynaptic membrane.

A

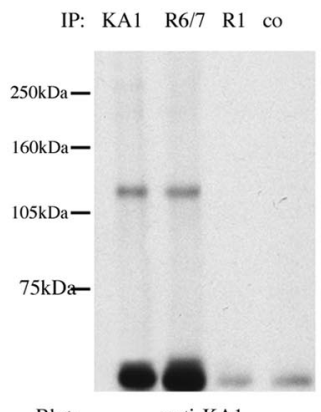

Blot:

anti-KA1
KA1 R6/7 co $\quad$ KAl R1 co

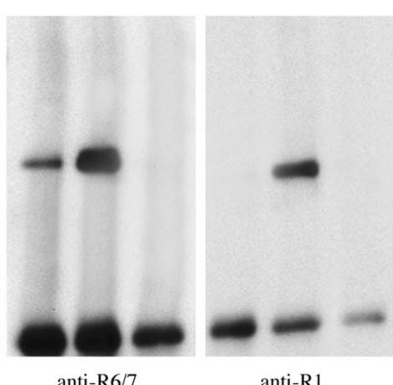

B

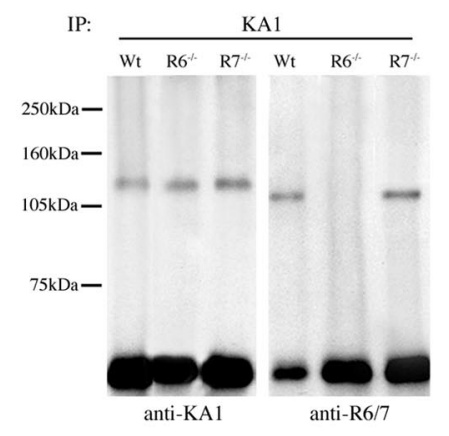

Figure 6. Immunoprecipitation of KA1 and GluR6/7 subunits from mouse hippocampus. $A$, Representative immunoprecipitations from wild-type mouse. Left, Immunoprecipitation with anti-KA1 and anti-GluR6/7 (R6/7) antibodies results in a KA1immunoreactive band detected in Western blots from wild-type mice, whereas no KA1 immunoreactivity is visible after immunoprecipitation with the AMPA receptor subunit GluR1 (R1), or in the control lane, where no antibody was used. Middle, GluR6/7 immunoreactive bands are visible after immunoprecipitation with anti-KA1 and anti-GluR6/7 antibodies. Right, GluR1 does not coprecipitate with KA1. B, Coimmunoprecipitations using KA1 antibodies from wild-type (WT) and GluR6 ${ }^{-1-}$ and GluR7 ${ }^{-1-}$ mice. Left, KA1-immunopositive bands are shown in wild-type, GluR6 ${ }^{-1-}$, and GluR7 ${ }^{-1}$ - mice. Right, Anti-KA1 immunoprecipitation shows GluR6/7 immunoreactivity in wild-type and $\mathrm{GluR7} 7^{-1}$ mice but not in GluR6 ${ }^{-1-}$ mice.

units are localized presynaptically and postsynaptically at mossy fiber synapses. KAl showed higher presynaptic expression, whereas KA2 was more abundant at postsynaptic spines. We further showed that KA1, KA2, and GluR6 subunits coassemble in the hippocampus.

\section{Antibody specificity and light microscopic distribution of kainate receptors}

We generated a new polyclonal antibody to the $\mathrm{C}$ terminal of the KA1 kainate receptor subunit to study the distribution of this subunit in the brain and its coassembly with other kainate receptor subunits. The antibody proved to be highly selective for KA1 and did not cross-react with other members of the kainate or AMPA receptor families. KA1 immunoreactivity in mouse brain was confined mainly to the hippocampus and cerebellum and to scattered neurons of cortical layers II and $\mathrm{V}$. This restricted staining pattern, unique among the kainate subtypes of glutamate receptors, is consistent with the distribution of KA1 mRNA. In the hippocampus, KA1 mRNA is expressed in DG granule cells, in CA3 pyramidal cells, and to a low degree in the CA1 pyramidal layer (Werner et al., 1991; Bahn et al., 1994; Wüllner et al., 1997). Our immunohistochemical experiments demonstrate that KA1 protein appears throughout the polymorphic layer of the DG and in the stratum lucidum. Granule cell axons from the DG, the mossy fibers, pass through these areas and make synaptic contacts with hilar neurons before terminating on CA3 pyramidal cells and interneurons. These findings support earlier radioligand binding studies suggesting high-affinity kainate receptors on presynaptic mossy fiber terminals (Monaghan and Cotman, 1982; Represa et al., 1987).

The distribution of KA1 was mapped previously using a distinct antibody (Fogarty et al., 2000). Although the specificity of their antibody was not tested on other kainate receptor subunit proteins, our results are in general agreement with a single striking exception. The previous study reported KA1 immunoreactivity at the light microscopic level in the stratum lucidum, but at the EM level mossy fiber terminals and postsynaptic densities in the stratum lucidum were not stained, in clear contrast to our strong labeling of these structures. Curiously, Fogarty et al. (2000) found KA1 immunoreactivity exclusively in the dendritic structures apposed to associational-commissural synapses, which do not have detectable kainate receptor currents (Castillo et al., 1997; Vignes and Collingridge, 1997; Mulle et al., 1998). It is possible that this discrepancy arises from different methods of preparing the tissues, experimental conditions, or sensitivities of the antisera. Alternatively, it might reflect a real difference in kainate receptor composition between rats (Fogarty et al., 2000) and mice (our study).

The antibody we generated to the C-terminal part of the KA2 subunit showed an immunoreactive band in brain extracts from wild-type but not from $\mathrm{KA} 2^{-/-}$mice, thereby demonstrating that this antibody recognizes only the KA2 subunit. KA2 staining appears in many structures throughout the brain, and the widespread distribution at the light microscopic level is consistent with an earlier study on KA2 protein expression in rat brain (Petralia et al., 1994). The hilus and stratum lucidum, the projection areas of the mossy fibers, showed neuropilar staining that was completely absent in brain sections from $\mathrm{KA} 2^{-1-}$ mice (Contractor et al., 2003), supporting physiological evidence for mossy fiber kainate receptors that contain the KA2 protein.

We used a polyclonal antibody that recognizes GluR6 and GluR7 subunits in combination with gene-targeted mice to study 


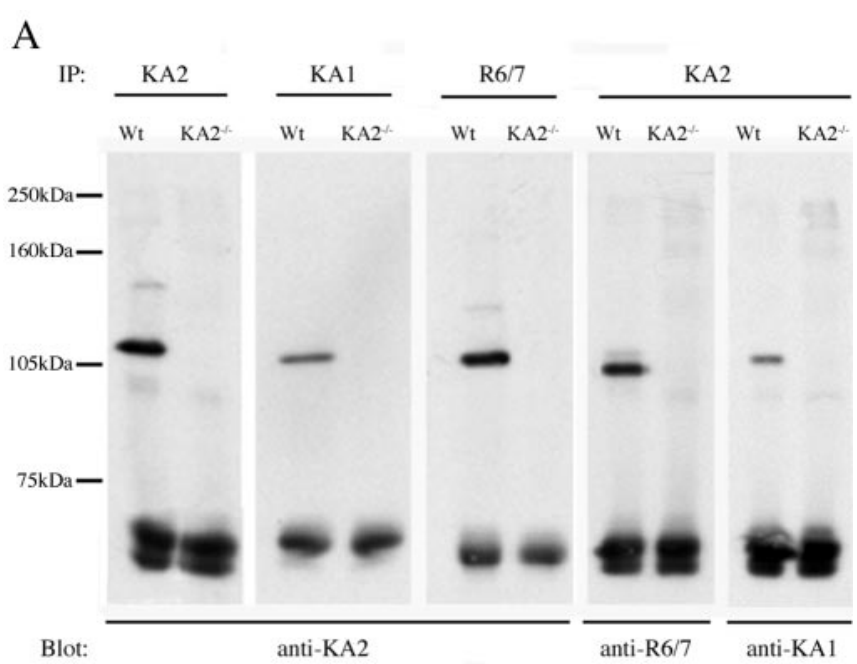

B

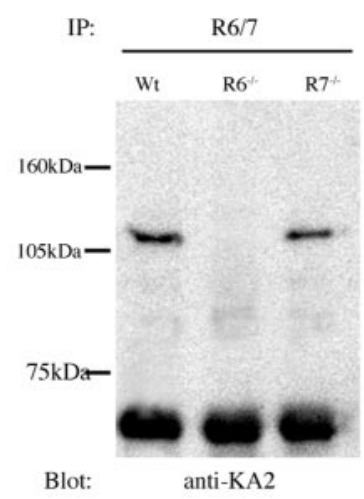

Figure 7. Immunoprecipitation of $K A 2, K A 1$, and $G l u R 6 / 7$ subunits from mouse hippocampus. $A$, Left, Immunoprecipitation with anti-KA2 antibody shows KA2 immunoreactivity in hippocampal extracts from wild-type mice (Wt) but not KA2 ${ }^{-1}$ mice. Middle, Coimmunoprecipitation of KA2 with KA1 in wild-type mouse hippocampus. KA2 immunoprecipitates with anti-GluR6/7 antibodies from the hippocampus of wild-type mice. Right, Coprecipitations of GluR6/7 and KA1 proteins with anti-KA2 antibodies in wild-type but not KA2 ${ }^{-1-}$ mice. B, KA2 subunits coprecipitate with GluR6/7 antibodies from hippocampal membranes from wild-type and GluR7 ${ }^{-1-}$ mice but not from GluR6 ${ }^{-1-}$ mice.

the regional distribution of these subunits and their coassembly with other kainate receptor subunits. The antibody gave a similar regional distribution pattern in wild-type mice as that described in previous results using rats (Petralia et al., 1994). GluR6/7 immunohistochemistry in mice lacking either the GluR6 or GluR7 subunits revealed that the staining observed in the stratum lucidum and CA3 pyramidal cells represents GluR6 immunoreactivity. In the hippocampus of GluR6 ${ }^{-1-}$, GluR6/7 staining was confined to the somatodendritic regions of dentate gyrus granule neurons. The lack of staining in the stratum lucidum may reflect a defect in targeting of GluR7 to mossy fiber terminals in the absence of GluR6 subunits. Alternatively, it could support a central role for GluR6 in the formation of presynaptic and postsynaptic kainate receptors in the CA3 region, as was concluded from previous biochemical (Wenthold et al., 1994) and physiological (Mulle et al., 1998; Contractor et al., 2000, 2001) experiments.

\section{Ultrastructural localization of KA1 and KA2 in mossy fiber synapses}

The localization of kainate receptors to presynaptic compartments has been described in a previous study in rat spinal cord
(Hwang et al., 2001). Early studies in rat on $\left[{ }^{3} \mathrm{H}\right]$ kainate binding in the hippocampus further suggested the existence of presynaptic kainate receptors on mossy fiber terminals (Represa et al., 1987). Our EM analysis of the distribution of small immunogold particles demonstrate that KA1 and KA2 subunits are localized to presynaptic mossy fiber boutons and dendritic spines. KA1 subunits were present in higher amounts near the presynaptic membrane as compared with the postsynaptic compartment (Fig. 5). In contrast, KA2 immunoreactivity was predominantly postsynaptic, although a small distribution peak was apparent near the presynaptic membrane. Similarly, an earlier EM study using preembedding enzymatic labeling found postsynaptic KA2 labeling (Petralia et al., 1994). The latter study also noted labeling in presumptive mossy fibers adjacent to mossy terminals; this is consistent with the presence of some immunogold labeling for KA2 seen in the present study. In addition to synaptic membranes, presynaptic staining was observed in vesicle-like structures within mossy fiber boutons. Glutamate receptor subunits have been detected in cytoplasmic vesicles in postsynaptic compartments (Racca et al., 2000; Lee et al., 2001), and it seems likely that the localization of KA1 and KA2 in vesicular structures at mossy fiber boutons similarly arises from localization of these subunits in endosomal compartments and trafficking vesicles.

\section{Kainate receptors in hippocampal mossy fibers}

Evidence for the existence of presynaptic kainate receptors on mossy fiber terminals arises mainly from electrophysiological data suggesting that presynaptic kainate receptors modulate mossy fiber synaptic transmission (Vignes et al., 1998; Contractor et al., 2000, 2001; Kamiya and Ozawa, 2000; Schmitz et al., 2001a). In particular, synaptic release of glutamate from either mossy fibers or associational-commissural fibers can activate mossy fiber kainate receptors, thereby modulating axon excitability and glutamate release (Schmitz et al., 2000; Contractor et al., 2001; Lauri et al., 2001). These physiological studies provide strong evidence that kainate receptors are located on mossy fiber axons and perhaps on presynaptic terminals.

Physiological attempts to discern the subunit composition of presynaptic and postsynaptic kainate receptors yielded contrasting interpretations. Pharmacological experiments using both commercial and proprietary compounds support a role for GluR5-containing receptors in mossy fiber transmission and plasticity (Vignes et al., 1997, 1998; Bortolotto et al., 1999; Lauri et al., 2001); however, functional properties of presynaptic and postsynaptic kainate receptors appear to be unaltered in GluR5 $^{-I-}$ mice (A. Contractor, personal communication). In contrast, electrophysiological recordings using other kainate receptor knock-out mice demonstrated that GluR6 and KA2 subunits are critical constituents of kainate receptors that modulate axonal excitability as well as short- and long-term mossy fiber plasticity (Contractor et al., 2000, 2001, 2003). Our EM localization and immunoprecipitation results support the hypothesis that presynaptic kainate receptors in mossy fiber boutons are formed from heteromeric combinations of GluR6, KA1, and KA2 subunits. Unfortunately, the ideal tools that would resolve these disparate observations are not available, for example, GluR6selective agonists or antagonists, or GluR5 subunit-specific antibodies. We have instead generated new resources, the KA1 and KA2 antibodies, to determine whether these high-affinity subunits are positioned appropriately to play a role in modulation of mossy fiber synaptic transmission.

Postsynaptic kainate receptor-mediated EPSCs were altered in $\mathrm{KA}^{-1-}$ mice (Contractor et al., 2003) and were eliminated in 
GluR6 $^{-/-}$mice (Mulle et al., 1998), consistent with our current biochemical results and with earlier morphological studies showing that both subunits were localized to postsynaptic densities at mossy fiber synapses (Petralia et al., 1994). Our current anatomical studies suggest that postsynaptic kainate receptors, like presynaptic receptors, contain KA1 and KA2 subunits (Figs. 4, 5). As discussed previously, KA1, KA2, and GluR6 subunits coprecipitated from hippocampal extracts, leading to the hypothesis that postsynaptic kainate receptors at mossy fiber synapses are likely to contain KA1, KA2, and GluR6 subunits.

In summary, our results strongly support the hypothesis that kainate receptors, formed from GluR6, KA1, and KA2 subunits, are expressed at presynaptic and postsynaptic sites in mossy fiber-CA3 pyramidal cell synapses, where they are ideally situated to act as facilitatory autoreceptors as well as mediate a component of the EPSCs. The differential localization of KA1 and KA2 subunits to presynaptic and postsynaptic mossy fiber synapses may further point to interesting functional variabilities of heteromeric receptor complexes.

\section{References}

Bahn S, Volk B, Wisden W (1994) Kainate receptor gene expression in the developing rat brain. J Neurosci 14:5525-5547.

Bortolotto ZA, Clarke VR, Delany M, Parry MC, Smolders I, Vignes M, Ho KH, Miu P, Brinton BT, Fantaske R, Ogden A, Gates M, Ornstein PL, Lodge D, Bleakman D, Collingridge GL (1999) Kainate receptors are involved in synaptic plasticity. Nature 402:297-301.

Bureau I, Bischoff S, Heinemann SF, Mulle C (1999) Kainate receptormediated responses in the CA1 field of wild-type and GluR6-deficient mice. J Neurosci 19:653-663.

Castillo PE, Malenka RC, Nicoll RA (1997) Kainate receptors mediate a slow postsynaptic current in hippocampal CA3 neurons. Nature 388:182-186.

Contractor A, Swanson GT, Sailer A, O'Gorman S, Heinemann SF (2000) Identification of the kainate receptor subunits underlying modulation of excitatory synaptic transmission in the CA3 region of the hippocampus. J Neurosci 20:8269-8278.

Contractor A, Swanson G, Heinemann SF (2001) Kainate receptors are involved in short- and long-term plasticity at mossy fiber synapses in the hippocampus. Neuron 29:209-216.

Contractor A, Sailer AW, Darstein M, Maron C, Xu J, Swanson G, Heinemann SF (2003) Loss of kainate receptor-mediated heterosynaptic facilitation of mossy fiber synapses in KA2-/- mice. J Neurosci 23:422-429.

Dingledine R, Borges K, Bowie D, Traynelis SF (1999) The glutamate receptor ion channels. Pharmacol Rev 51:7-61.

Egebjerg J, Heinemann SF (1993) $\mathrm{Ca}^{2+}$ permeability of unedited and edited versions of the kainate selective glutamate receptor GluR6. Proc Natl Acad Sci USA 90:755-759.

Fogarty DJ, Perez-Cerda F, Matute C (2000) KA1-like kainate receptor subunit immunoreactivity in neurons and glia using a novel anti-peptide antibody. Brain Res Mol Brain Res 81:164-176.

Herb A, Burnashev N, Werner P, Sakmann B, Wisden W, Seeburg PH (1992) The KA2 subunit of excitatory amino acid receptors shows widespread expression in brain and forms ion channels with distantly related subunits. Neuron 8:775-785.

Hollmann M, Heinemann S (1994) Cloned glutamate receptors. Annu Rev Neurosci 17:31-108.

Hwang SJ, Pagliardini S, Rustioni A, Valtschanoff JG (2001) Presynaptic kainate receptors in primary afferents to the superficial laminae of the rat spinal cord. J Comp Neurol 436:275-289.

Kamiya H, Ozawa S (2000) Kainate receptor-mediated presynaptic inhibition at the mouse hippocampal mossy fibre synapse. J Physiol (Lond) 523:653-665.
Lauri SE, Delany C, Clarke VR, Bortolotto ZA, Ornstein PL, Isaac JTR, Collingridge GL (2001) Synaptic activation of a presynaptic kainate receptor facilitates AMPA receptor-mediated synaptic transmission at hippocampal mossy fibre synapses. Neuropharmacology 41:907-915.

Lee SH, Valtschanoff JG, Kharazia VN, Weinberg R, Sheng M (2001) Biochemical and morphological characterization of an intracellular membrane compartment containing AMPA receptor. Neuropharmacology 41:680-692.

Merighi A (1992) Post-embedding electron microscopic immunocytochemistry. In: Electron microscopic immunocytochemistry, principles and practice (Polak JM, Priestley JV, eds), pp 51-85. New York: Oxford.

Monaghan DT, Cotman CW (1982) The distribution of $\left[{ }^{3} \mathrm{H}\right]$ kainic acid binding sites in rat CNS as determined by autoradiography. Brain Res 252:91-100.

Mulle C, Sailer A, Perez-Otano I, Dickinson-Anson H, Castillo PE, Bureau I, Maron C, Gage FH, Mann JR, Bettler B, Heinemann SF (1998) Altered synaptic physiology and reduced susceptibility to kainate-induced seizures in GluR6-deficient mice. Nature 392:601-605.

Petralia RS, Wenthold RJ (1999) Immunocytochemistry of NMDA receptors. In: Methods in molecular biology: NMDA receptor protocols ( $\mathrm{Li}, \mathrm{M}$ ed), pp 73-92. Totowa, NJ: Humana.

Petralia RS, Wang YX, Wenthold RJ (1994) Histological and ultrastructura localization of the kainate receptor subunits, KA2 and GluR6/7, in the rat nervous system using selective antipeptide antibodies. J Comp Neurol 349:85-110.

Racca C, Stephenson FA, Streit P, Roberts JD, Somogyi P (2000) NMDA receptor content of synapses in stratum radiatum of the hippocampal CA1 area. J Neurosci 20:2512-2522.

Represa A, Tremblay E, Ben-Ari Y (1987) Kainate binding sites in the hippocampal mossy fibers: localization and plasticity. Neuroscience 20:739-748.

Schiffer HH, Swanson GT, Heinemann SF (1997) Rat GluR7 and a carboxyterminal splice variant, GluR7b, are functional kainate receptor subunits with a low sensitivity to glutamate. Neuron 19:1141-1146.

Schmitz D, Frerking M, Nicoll RA (2000) Synaptic activation of presynaptic kainate receptors on hippocampal mossy fiber synapses. Neuron 27:327-338

Schmitz D, Mellor J, Nicoll RA (2001a) Presynaptic kainate receptor mediation of frequency facilitation at hippocampal mossy fiber synapses. Science 291:1972-1976.

Schmitz D, Mellor J, Frerking M, Nicoll RA (2001b) Presynaptic kainate receptors at hippocampal mossy fiber synapses. Proc Natl Acad Sci USA 98:11003-11008.

Sommer B, Burnashev N, Verdoorn TA, Keinanen K, Sakmann B, Seeburg PH (1992) A glutamate receptor channel with high affinity for domoate and kainate. EMBO J 11:1651-1656.

Vignes M, Collingridge GL (1997) The synaptic activation of kainate receptors. Nature 388:179-182.

Vignes M, Clarke VR, Parry MJ, Bleakman D, Lodge D, Ornstein PL, Collingridge GL (1998) The GluR5 subtype of kainate receptor regulates excitatory synaptic transmission in areas CA1 and CA3 of the rat hippocampus. Neuropharmacology 37:1269-1277.

Wenthold RJ, Trumpy VA, Zhu WS, Petralia RS (1994) Biochemical and assembly properties of GluR6 and KA2, two members of the kainate receptor family, determined with subunit-specific antibodies. J Biol Chem 269:1332-1339.

Werner P, Voigt M, Keinanen K, Wisden W, Seeburg PH (1991) Cloning of a putative high-affinity kainate receptor expressed predominantly in hippocampal CA3 cells. Nature 351:742-744.

Wisden W, Seeburg PH (1993) A complex mosaic of high-affinity kainate receptors in rat brain. J Neurosci 13:3582-3598.

Wüllner U, Standaert DG, Testa CM, Penney JB, Young AB (1997) Differential expression of kainate receptors in the basal ganglia of the developing and adult rat brain. Brain Res 768:215-223. 